\title{
The use of babosa (Aloe vera) in treating burns: a literature review
}

\author{
O uso da babosa (Aloe vera) no tratamento de queimaduras: uma revisão da literatura
}

\author{
L. R. Zago ${ }^{\mathrm{a}}$ (D), K. Prado ${ }^{\mathrm{a} *}$ (D), V. L. Benedito ${ }^{\mathrm{a}}$ (D) and M. M. Pereira ${ }^{\mathrm{a}}$ (1) \\ ${ }^{a}$ Centro Universitário São Camilo, Curso de Medicina, São Paulo, SP, Brasil
}

\begin{abstract}
Alo vera is a centenary remedy use for minor wounds and burns, but its mechanism of wound healing has not been know since. This article will evaluate and gather evidence of the effectiveness and safety of the use of aloe vera in the treatment of burns. A systematic review was carried out on the databases: MEDLINE, LILACS, DECS, SCIELO, in the last 7 years, with the descriptors: "Aloe", "Burns" and "treatment". 16 articles were found. After using the exclusion criteria; research in non-humans and literature review; 5 articles were selected. The article Teplick et al. (2018) performed an in vitro clinical experiment in A. Vera solution, and demonstrated that there was proliferation and cell migration of human skin fibroblasts and keratinocytes, in addition to being protective in the death of keratonocytes. That is, it accelerates the healing of wounds. Muangman et al. (2016), evaluated 50 patients with $20 \%$ of the total body surface area burned with second-degree burns, between $18-60$ years old, with half of the group receiving gauze dressings with soft paraffin containing $0.5 \%$ chlorhexidine acetate and the other half receiving polyester dressings containing extracts of medicinal plants mainly Aloe Vera. It had positive results, a higher healing speed and shorter hospital stay compared to the control group. Hwang et al. (2015) investigated the antioxidant effects of different extracts from 2,4,6,8,12 months of Aloe Vera. And the 6-month concentrated extract of $0.25 \mathrm{mg} / \mathrm{mL}$ had a higher content of flavonoids ( $9.750 \mathrm{mg}$ catechin equivalent $/ \mathrm{g}$ extract) and polyphenols ( $23.375 \mathrm{mg}$ gallic acid equivalent / g extract) and the greater ferric reducing antioxidant power ( $0.047 \mathrm{mM}$ equivalent ferrous sulfate / $\mathrm{mg}$ extract), that is, greater potential for free radical scavenging and also a protective effect against oxidative stress induced by tert-butyl hydroperoxide (t-BHP), suggesting evidence of a bioactive potential of A. vera. However, in the article Kolacz et al. (2014) suggested as an alternative treatment the use of Aloe Vera dressing in combination with honey, lanolin, olive oil, wheat germ oil, marshmallow root, wormwood, comfrey root, white oak bark, lobelia inflata, glycerin vegetable oil, beeswax and myrrh, without obtaining significant and conclusive results that would allow the conventional treatment of burns to be subsidized. Finally, in the article by Zurita and Gallegos (2017), it carried out a descriptive cross-sectional study with 321 people, both sexes between 17-76 years of age, of an inductive nature, exploring the experience of this population and their behavioral attitudes regarding the treatment of dermatoses. Aloe vera had $13.8 \%$ cited by individuals in the treatment of acne and 33.6\% in the treatment of burns. Even with evidence that suggests the efficacy in the treatment of burns with the use of Aloe Vera extract, further clinical trials with larger sample space on the use of Aloe vera dressings in medium burns are suggested for further conclusions.
\end{abstract}

Keywords: burns, Aloe vera, treatment.

\section{Resumo}

Alo vera é um remédio centenário usado para pequenas feridas e queimaduras, mas seu mecanismo de cicatrização de feridas não foi conhecido desde então. Este artigo avaliará e reunirá evidências da eficácia e segurança do uso de aloe vera no tratamento de queimaduras. Realizada revisão Sistemática nas bases de dados: MEDLINE, LILACS, DECS, SCIELO, nos últimos 7 anos, com os descritores: "Aloe", "Burns" and "treatment". Foram encontrados 16 trabalhos. Após utilizarmos os critérios de exclusão; pesquisa em nao humanos e revisão da literatura ; foram selecionados 5 artigos. $O$ artigo Teplick et al. (2018) realizou um experimento clinico in vitro em solução de A. Vera, e demonstrou que houve proliferação e migração celular de fibroblastos e queratinócitos de pele humana, além de ser protetor na morte de queratonócitos. Ou seja, acelera a cicatrização das feridas. Já Muangman et al. (2016), avaliou 50 pacientes com $20 \%$ do total da área superficial corporal queimada com queimaduras de segundo grau, entre 18-60 anos, tendo metade do grupo como controle recebendo curativos de gaze com parafina mole contendo $0,5 \%$ acetado de clorexidina e a outra metade recebendo curativos com poliéster contendo extratos de plantas medicinais principalmente Aloe Vera. Teve resultados positivos, uma maior velocidade de cicatrização e menor tempo de internação comparado ao grupo controle. Já Hwang et al. (2015) investigou os efeitos antioxidante de diferentes extratos de 2,4,6,8,12 meses da Aloe Vera. E o extrato com 6 meses concentrado de $0,25 \mathrm{mg} / \mathrm{mL}$ teve

*e-mail: karinaprado18@gmail.com

Received: February 27, 2021 - Accepted: May 5, 2021

This is an Open Access article distributed under the terms of the Creative Commons Attribution License, which permits unrestricted use, distribution, and reproduction in any medium, provided the original work is properly cited. 
maior teor de flavanóides (9,750 mg equivalente catequina / g extrato) e polifenóis (23,375 mg equivalente ácido gálico / g extrato) e o maior poder antioxidante redutor férrico $(0,047 \mathrm{mM}$ de sulfato ferroso equivalente / extrato $\mathrm{mg}$ ), ou seja, maior potencial de eliminação de radicais livres e também efeito proteror contra o estresse oxidativo induzido por hidroperóxido de terc-butila (t-BHP), sugerindo indícios de um potencial bioativo da A. vera. Porém, no artigo Kolacz et al. (2014) sugeriu como tratamento alternativo o uso do curativo com Aloe Vera em conjunto de mel, lanolina, azeite de oliva, óleo de gérmen de trigo, raiz de marshmallow, absinto, raiz de confrei, casca de carvalho branco, lobelia inflata, glicerina vegetal, cera de abelha e mirra, não obtendo resultados significativos e conclusivos que permitam subsidiar o tratamento convencional das queimaduras. Por fim, no artigo de Zurita and Gallegos (2017), realizou um estudo descritivo transversal com 321 pessoas, ambos os sexos entre 17-76 anos, de natureza indutiva, explorando a vivência dessa população e suas atitudes comportamentais quanto ao tratamento de dermatoses. Aloe vera teve $13,8 \%$ citada pelos indivíduos no tratamento de acne e 33,6\% no tratamento de queimaduras. Mesmo tendo evidências que sugerem a eficácia no tratamento de queimaduras com o uso do extrato da Aloe Vera, sugere-se mais ensaios clínicos com espaço amostral maior sobre o uso de curativos de Aloe vera em médio queimados para maiores conclusões.

Palavras-chave: queimaduras, Aloe vera, tratamento.

\section{Introduction}

Aloe vera or Aloe barbadensis miller belongs to the Asphodelaceae family and is a shrub or arborescent plant, perennial, xerophytic, succulent and green in color. It grows preferentially in the dry regions of Africa, Asia, Europe and America. It is also popularly known as aloe, caraguatá-dejardim or aloe. The name Aloe has its contested origin, possibly from Greek or Arabic, but the meaning in both languages would be the same: bitter and shiny, which are characteristic of its gel. Vera, of Latin origin, means true (Surjushe et al., 2008; Saad, 2016; Freitas et al., 2014).

The first record of its medicinal use was made on a Mesopotamian clay tablet dating from 2100 BC and the use of its gel became popular in the treatment of skin burns around the 1930s, after the disclosure of its success in burns by radiation (Surjushe et al., 2008).

Burns, in turn, result from injuries resulting from agents capable of producing excessive heat that damages body tissues and causes cell death (Mandelbaum et al., 2003). Thus, the injury repair process involves the processes of coagulation, inflammation, proliferation, wound contraction and remodelin (Brasil, 2012).

Thus, Alo vera has become popularly known as a remedy for minor wounds and burns since then, but its mechanism of wound healing is not known. Thus, the objective of this work is to evaluate and gather evidence of the effectiveness and safety of the use of aloe vera in the treatment of burns.

\section{Methods}

The present study is a bibliographic review of the last 7 years (2014-2021), of an exploratory nature, in order to gather evidence on the use of Aloe Vera in the treatment of burns; from a secondary source, since analysis, syntheses and evaluation of results are described here; with treatment of qualitative and quantitative results, depending on the study we evaluated.

A selection, study and appreciation of a selected set of scientific articles was made, mainly those published in the last seven years, in an orderly and structured manner, with the aim of elucidating the therapeutic use of Aloe vera in patients with burns.
The construction of the work was developed as follows: definition of the research area and theme, careful choice of descriptors, choice of references to be part of the study, reading of the sources and analysis of them, presentation of the information in a compiled and synthetic way.

The databases used in this study were: Scientific Eletronic Library Online (Scielo), Medical Literature Analysis and Retrieval System Online (Medline), Latin American and Caribbean Literature in Health Sciences (LILACS) and Health Sciences Descriptors (DECS). The following descriptors were used: "Aloe" or Aloe barbadensis Miller, or A. vera, or Aloe barbadensis or Aloe vera, "Burns" and "treatment" or therapeutics; the exclusion criteria being: review articles, articles that did not talk about treatment in burns and those of inclusion: research in human adults. We found 16 articles, after applying the inclusion and exclusion criteria, 10 articles were left, for the composition of this bibliographic review.

\section{Results}

Using the 5 articles, Teplicki et al. (2018) performed an in vitro clinical experiment in A. Vera solution, and demonstrated that there was proliferation and cell migration of human skin fibroblasts and keratinocytes, in addition to being protective in the death of keratonocytes. That is, it accelerates the healing of wounds. Muangman et al. (2016), evaluated 50 patients with $20 \%$ of the total body surface area burned with second-degree burns, between 18-60 years old, with half of the group receiving gauze dressings with soft paraffin containing $0.5 \%$ chlorhexidine acetate and the other half receiving polyester dressings containing extracts of medicinal plants mainly Aloe Vera. It had positive results, a higher healing speed and shorter hospital stay compared to the control group. However, there were no differences in the analogue pain scale and there was 1 complication in the group studied due to infection by Pseudomonas aeruginosa.

Hwang et al. (2015) investigated the antioxidant effects of different extracts from 2,4,6,8,12 months of Aloe Vera. And the 6-month concentrated extract of $0.25 \mathrm{mg} / \mathrm{mL}$ had a higher content of flavonoids ( $9.750 \mathrm{mg}$ catechin equivalent/g extract) and polyphenols ( $23.375 \mathrm{mg}$ gallic acid equivalent / $g$ extract) and the greater ferric reducing antioxidant power $(0.047 \mathrm{mM}$ equivalent ferrous sulfate / mg extract), that is, greater potential for free radical 
scavenging and also a protective effect against oxidative stress induced by tert-butyl hydroperoxide ( $\mathrm{t}-\mathrm{BHP}$ ), suggesting evidence of a bioactive potential of A. vera

However, in the article Kolacz et al. (2014) suggested as an alternative treatment the use of Aloe Vera dressing in combination with honey, lanolin, olive oil, wheat germ oil, marshmallow root, wormwood, comfrey root, white oak bark, lobelia inflata, glycerin vegetable oil, beeswax and myrrh, without obtaining significant and conclusive results that would allow the conventional treatment of burns to be subsidized.

Finally, in the article by Zurita and Gallegos (2017), it carried out a descriptive cross-sectional study with 321 people, both sexes between 17-76 years of age, of an inductive nature, exploring the experience of this population and their behavioral attitudes regarding the treatment of dermatoses. Aloe vera had $13.8 \%$ cited by individuals in the treatment of acne and $33.6 \%$ in the treatment of burns.

\section{Discussion}

Aloe vera has been used in traditional medicine for the treatment of a variety of ailments, such as wounds and burns. It is popularized by the society that skin diseases such as acne, burns, itching, are treated with aloe vera (Aloe vera), allowing to prevent and cure the referred skin problems. This is due to the anti-inflammatory and healing capabilities contained in the aqueous extracts of the plant (Moscoso, 2012; Zafra-Ramíres, 2016) also seen in the article by Teplicki et al. (2018), which have therapeutic properties in terms of antimicrobial inhibition and facilitation of the healing process, as determined in a study carried out on New Zealand white rats and rabbits (Balbino et al., 2005) and also shown in the clinical trial by Muangman et al. (2016).

Another important point is the indiscriminate use of the population observed in the article Zurita and Gallegos (2017) since Aloe Vera may also have the presence of anthraquinones, a substance that relieves constipation. However, the use of these species should be viewed with caution, especially during the first trimester of pregnancy, as anthraquinone has a stimulatory effect on the large intestine and may cause reflexes in the uterine muscles, inducing abortion, and its oral use during pregnancy is not recommended (Duarte et al., 2018).

\section{Conclusion}

Evidence suggests efficacy in the treatment of burns with the use of Aloe Vera extract. However, few studies have examined the antioxidant capabilities of $A$. vera plants during different growth periods, and there are few clinical trials and in vitro studies that show such bioactive potential.

For this reason, it is suggested that more trials with a larger sample space on the use of Aloe vera dressings in medium burns for greater conclusions.

\section{References}

BALBINO, C.A., PEREIRA, L.M. and CURI, R., 2005. Processo de reparação de tecidos: abordagens terapêuticas. Revista Brasileira de Cieências Farmacêuticas, vol. 41, no. 1, pp. 27-51. http://dx.doi. org/10.1590/S1516-93322005000100004.

BRASIL. Ministério da Saúde - MS, 2012 [viewed 19 April 2019]. Cartilha para tratamento de emergência das queimaduras [online]. Brasilia. Available from: https://bvsms.saude.gov.br/bvs/ publicacoes/cartilha_tratamento_emergencia_queimaduras.pdf

DUARTE, A.F.S., MARTINS, A.L.C., MIGUEL, M.D. and MIGUEL, O.G., 2018. O uso de plantas medicinais durante a gravidez e amamentação. Visão Acadêmica, vol. 18, no. 4, pp. 126-139. http://dx.doi.org/10.5380/acd.v18i4.55983.

FREITAS, V.S., RODRIGUES, R.A.F. and GASPI, F.O.G., 2014. Propriedades farmacológicas da Aloe vera (L.) Burm. f. Revista Brasileira de Plantas Medicinais, vol. 16, no. 2, pp. 299-307. http:// dx.doi.org/10.1590/S1516-05722014000200020.

HWANG, J.W., KIM, E.K., KIM, Y.S., LEE, J.W., LEE, J.J., PYO, H.J., MOON, S.H., JEON, B.T. and PARK, P.J., 2015. Growth period effects on the protective properties of Aloe vera against t-BHP-induced oxidative stress in chang cells. Journal of Microbiology and Biotechnology, vol. 25, no. 12, pp. 2072-2081. http://dx.doi. org/10.4014/jmb.1504.04035. PMid:26370795.

KOLACZ, N.M., JAROCH, M.T., BEAR, M.L. and HESS, R.F., 2014. The effect of Burns \& Wounds (B\&W)/burdock leaf therapy on burn-injured Amish patients: a pilot study measuring pain levels, infection rates, and healing times. Journal of Holistic Nursing, vol. 32, no. 4, pp. 327-340. http://dx.doi. org/10.1177/0898010114525683. PMid:24668061.

MANDELBAUM, S.H., DI SANTIS, E.P. and MANDELBAUM, M.H.S., 2003. Cicatrização: conceitos atuais e recursos auxiliares - Parte I. Anais Brasileiros de Dermatologia, vol. 78, no. 4, pp. 393-408. http://dx.doi.org/10.1590/S0365-05962003000400002.

MOSCOSO, A.A., 2012 [viewed 4 February 2021]. Efeito antiinflamatório e cicatrizante do extrato liofilizado de Aloe Vera (Aloe Vera (L) burm. F.) Apresentado na forma de um gel farmacêtico. Available from: http://cybertesis.unmsm.edu. pe/handle/cybertesis/2591

MUANGMAN, P., PRADITSUKTAVORN, B., CHINAROONCHAI, K. and CHUNTRASAKUL, C., 2016. Clinical efficacy test of polyester containing herbal extract dressings in burn wound healing. The International Journal of Lower Extremity Wounds, vol. 15, no. 3, pp. 203-212. http://dx.doi.org/10.1177/1534734616652552. PMid:27440796.

SAAD, G., 2016. Fitoterapia contemporânea: tradição e ciência na prática clínica. Tradição e Ciência na Prática Clinica, vol. 30, no. 1, pp. 192-194.

SURJUSHE, A., VASANI, R. and SAPLE, D.G., 2008. Aloe vera: a short review. Indian Journal of Dermatology, vol. 53, no. 4, pp. 163-166. http://dx.doi.org/10.4103/0019-5154.44785. PMid:19882025.

TEPLICKI, E., MA, Q., CASTILLO, D.E., ZAREI, M., HUSTAD, A.P., CHEN, J. and LI, J., 2018. The effects of Aloe vera on wound healing in cell proliferation, migration, and viability. Wounds: a Compendium of Clinical Research and Practice, vol. 30, no. 9, pp. 263-268. PMid:30256753.

ZAFRA-RAMÍRES, J. 2016. Aplicabilidade da aloe vera em feridas, queimaduras e úlceras: revisão bibliográfica. [viewed 4 February 2021]. Available from: http://tauja.ujaen.es/ handle/10953.1/2905

ZURITA, M.G. and GALLEGOS, D.Z., 2017. Plantas medicinales utilizadas en el tratamiento de enfermedades de la piel en comunidades rurales de la provincia de Los Ríos - Ecuador. Anales. Universidad Nacional Mayor de San Marcos. Facultad de Medicina, vol. 78, no. 3, pp. 315. http://dx.doi.org/10.15381/ anales.v78i3.13767. 